\title{
LAKI-LAKI ATAU PEREMPUAN, SIAPA YANG LEBIH CERDAS DALAM PROSES BELAJAR? SEBUAH BUKTI DARI PENDEKATAN ANALISIS SURVIVAL
}

\author{
Samsul Anwar'1, Inas Salsabila1, Rahmadaini Sofyan', Zaujatul Amna² \\ 1) Jurusan Statistika, Fakultas MIPA, Universitas Syiah Kuala, \\ Jl. Syech Abdurrauf, Kopelma Darussalam, Syiah Kuala, Banda Aceh, Indonesia 23111 \\ ${ }^{2)}$ Program Studi Psikologi, Fakultas Kedokteran, Universitas Syiah Kuala, \\ Jl. Tgk. Tanoeh Abee, Kopelma Darussalam, Syiah Kuala, Banda Aceh, Indonesia 23111 \\ samsul.anwar@unsyiah.ac.id
}

\begin{abstract}
This study aims to compare the level of intelligence between male and female, especially in the learning process in college. Someone who could complete their undergraduate study with a shorter period of time is assumed to have a higher level of intelligence. This research was conducted on Syiah Kuala University students who graduated on the second period of 2017 with a population of 758 people. The number of samples used was 262 people that were determined through Slovin formula with a margin error of 5\%. The sampling technique used was Stratified Random Sampling with scientific disciplines as the basis for population stratification. The data analysis method used was the Cox Proportional Hazard (Cox PH) model to find a graduation hazard ratio based on gender and scientific disciplines variables. This study showed that female students have $125.5 \%$ potential to graduate faster compare to male. More detail, female students have the potential of $127 \%$ to graduate faster on the field of social science, economics and humanities, and $123.9 \%$ on the field of sciences and technology. Survival analysis also showed that female student has higher probability to be able to complete their studies faster. Accordingly, it can be concluded that female have a higher level of intelligence than male, especially in the learning process in college.
\end{abstract}

Keywords: cox proportional hazard; hazard ratio; gender; intelligence; learning process

\begin{abstract}
Abstrak
Penelitian ini bertujuan untuk membandingkan tingkat kecerdasan antara laki-laki dan perempuan terutama dalam proses pembelajaran di perguruan tinggi. Seseorang yang dapat menyelesaikan masa studi Strata-1 dengan waktu yang lebih singkat diasumsikan memiliki tingkat kecerdasan yang lebih tinggi. Penelitian ini dilakukan terhadap mahasiswa/i Universitas Syiah Kuala yang diwisuda pada periode kedua tahun 2017 dengan populasi sebanyak 758 orang. Jumlah sampel yang digunakan adalah sebanyak 262 orang yang ditentukan melalui rumus Slovin dengan tingkat kesalahan 5\%. Teknik sampling yang digunakan adalah Stratified Random Sampling dengan disiplin bidang ilmu sebagai basis stratifikasi populasi. Metode analisis data yang digunakan adalah Cox Proportional Hazard (Cox PH) model untuk melihat besaran nilai hazard rasio kelulusan berdasarkan variabel jenis kelamin dan disiplin bidang ilmu yang dipelajari. Penelitian ini menunjukkan bahwa mahasiswi memiliki potensi $125,5 \%$ untuk lulus lebih cepat daripada mahasiswa. Lebih rinci, mahasiswi berpotensi $127 \%$ untuk lulus lebih cepat pada bidang ilmu Sosial, Ekonomi, dan Humaniora (Soshum), serta 123,9\% pada bidang ilmu Sains dan Teknologi (Saintek). Analisis survival juga menunjukkan bahwa mahasiswi memiliki peluang yang lebih besar untuk dapat menyelesaikan studi lebih cepat. Dengan demikian, dapat disimpulkan bahwa perempuan memiliki tingkat kecerdasan yang lebih tinggi dari pada laki-laki terutama dalam proses pembelajaran di perguruan tinggi.
\end{abstract}

Kata kunci: cox proportional hazard; hazard rasio; jenis kelamin; kecerdasan; proses belajar

\section{PENDAHULUAN}

Pendidikan pada dasarnya adalah usaha sadar dari setiap individu untuk menumbuh- kembangkan potensi sumber daya dengan cara mendorong dan memfasilitasi kegiatan belajar-mengajar. Syah (2010) menjelaskan bahwa pendidikan sebagai sebuah proses 
dengan metode-metode tertentu sehingga individu dapat memeroleh pengetahuan, pemahaman, dan cara bertingkah laku yang sesuai dengan kebutuhannya. Dalam bidang pendidikan, faktor kecerdasan merupakan salah satu faktor yang mempunyai peranan yang sangat penting, hal ini berkaitan dengan sejauh mana prestasi belajar yang dapat dicapai oleh individu terdidik. Secara umum terdapat dua faktor yang memengaruhi kemampuan pemahaman individu (misalnya mahasiswa/i) terhadap materi yang diberikan padanya, yaitu faktor internal yang meliputi kecerdasan individu dan faktor eksternal yang meliputi kondisi tempat belajar, sarana dan perlengkapan belajar, materi pelajaran dan kondisi lingkungan belajar (Walgito, 2010).

Kecerdasan sering didefinisikan sebagai kemampuan untuk beradaptasi (menyesuaikan diri) dengan lingkungan (Sternberg \& Kaufman, 2011). Kecerdasan sebagai unsur kognitif dianggap memegang peranan yang cukup penting dalam menentukan keberhasilan belajar seseorang (Azwar, 2012). Lebih lanjut, Azwar (2012) menjelaskan bahwa kecerdasan merupakan salah satu faktor internal dalam diri individu yang dapat memengaruhi kemampuan pemahaman individu terhadap materi ataupun stimulus yang diterima oleh individu tersebut. Khodijah (2014) mengemukakan bahwa tingkat kecerdasan atau dikenal dengan kemampuan intelektual seseorang diyakini sangat berpengaruh pada keberhasilan belajar yang akan dicapainya. Prestasi belajar biasanya berkorelasi searah dengan tingkat kecerdasan. Semakin tinggi tingkat kecerdasan seseorang, maka semakin tinggi prestasi belajar yang dapat dicapai oleh orang tersebut.

Perbedaan kecerdasan pada laki-laki dan perempuan sering dikaitkan dengan adanya perbedaan fisiologi otak, meskipun tidak serta merta berkaitan langsung dengan perbedaan kecerdasan. Rushton \& Ankney (2009) menyatakan bahwa volume otak berkorelasi dengan tingkat kecerdasan seseorang. Secara umum, laki-laki memiliki volume otak yang lebih besar dari pada perempuan (Ruigrok dkk., 2014). Orang dewasa memiliki otak dengan berat rata-rata sekitar $1,5 \mathrm{~kg}$, dengan volume sekitar 1.130 $\mathrm{cm}^{3}$ pada perempuan dan $1.260 \mathrm{~cm}^{3}$ pada laki-laki (Zaidi, 2010). Lebih lanjut, penelitian dari Pakkenberg dan Gundersen (1997) menunjukkan bahwa terdapat perbedaan jumlah rata-rata neuron neokorteks pada otak perempuan dan lakilaki sebesar $16 \%$, di mana terdapat sekitar 19 miliar neuron neokorteks pada otak perempuan dan 23 miliar pada otak laki-laki. Jaušovec dan Pahor (2017) menjelaskan bahwa terdapat hubungan yang positif antara volume otak dengan tingkat kecerdasan yang dijelaskan oleh asosiasi yang positif antara volume otak dengan jumlah neuron. Goriounova dkk., (2018) membuktikan bahwa kecerdasan manusia berhubungan dengan kompleksitas neuron, aksi potensial kinetika dan transfer informasi yang efisien dari input ke output dalam neuron kortikal.

Tingkat kecerdasan pada setiap individu adalah berbeda-beda, sebuah meta-analisis tahun 2014 tentang perbedaan jenis kelamin dalam pencapaian skolastik menemukan bahwa perempuan mengungguli laki-laki mulai dari tingkat pendidikan Sekolah Dasar (SD) sederajat, Sekolah Menengah Pertama (SMP) sederajat, Sekolah Menengah Atas (SMA) sederajat hingga tingkat perguruan tinggi. Hasil senada juga dijelaskan dalam penelitian meta-analisis yang dilakukan oleh Voyer dan Voyer (2014) terhadap 369 orang sampel dari tahun 1914 hingga 2011. Mereka menemukan bahwa prestasi pendidikan secara keseluruhan pada perempuan lebih baik sekitar 70 persen dari pada laki-laki. Penelitian meta-analisis yang dilakukan oleh Petersen (2018) terhadap lebih dari 11 juta peserta didik kelas 3 sampai 11 di Amerika menunjukkan bahwa perempuan sedikit lebih baik dari pada laki-laki dalam hal kemampuan verbal secara umum.

Akan tetapi, terdapat beberapa penelitian lain yang menyimpulkan hasil yang berbeda. 
Penelitian yang dilakukan oleh Zaidi (2010) menyimpulkan bahwa tidak adanya perbedaan antara laki-laki dan perempuan dalam hal kecerdasan, tetapi keduanya cenderung beroperasi dengan cara berbeda. Laki-laki dan perempuan menggunakan bagian otak yang berbeda dalam hal mengingat, merasakan emosi, mengenali wajah, memecahkan masalah dan membuat keputusan. Senada dengan hal tersebut, Stoet dan Geary (2015) menyatakan bahwa perbedaan jenis kelamin dalam pencapaian pendidikan tidak dapat dikaitkan dengan kesetaraan gender. Selain itu, Khaterina dan Garliah (2012) menyimpulkan bahwa tidak adanya perbedaan tingkat kecerdasan terutama kecerdasan emosional yang signifikan antara laki-laki dan perempuan.

Berdasarkan beberapa kesenjangan hasil penelitian di atas, maka perlu dilakukannya penelitian lanjutan terkait dengan ada atau tidaknya pengaruh jenis kelamin terhadap tingkat kecerdasan dalam proses belajar dan tingkat keberhasilan gender berdasarkan latar belakang keilmuannya. Adapun tujuan dari penelitian ini adalah untuk mengetahui perbedaan tingkat kecerdasan pada laki-laki dan perempuan berdasarkan bidang keilmuannya di Universitas Syiah Kuala yang akan dianalisis melalui pendekatan analisis survival. Penelitian dengan pendekatan analisis survival akan memberikan sudut pandang yang berbeda mengenai tingkat kecerdasan individu terutama dalam proses belajar di perguruan tinggi melalui analisis terhadap lamanya masa studi yang dijalani dalam menyelesaikan pendidikannya pada program Strata-1. Terdapat banyak faktor yang memengaruhi lama waktu mahasiswa/i dalam menyelesaikan pendidikan mereka. Dibutuhkan kemampuan beradaptasi (kecerdasan) yang baik terhadap faktorfaktor tersebut. Sehingga pendekatan ini dapat mengukur tingkat kecerdasan seseorang terutama dalam proses pembelajaran di perguruan tinggi secara lebih menyeluruh.

\section{METODE}

Penelitian ini menggunakan data sekunder mahasiswa/i yang telah menyelesaikan masa studi dan diwisuda pada Periode 2 (Februari - April) tahun 2017 dari 11 Fakultas program Strata-1 (S-1) yang ada di Universitas Syiah Kuala, Banda Aceh. Jumlah mahasiswa/i yang diwisuda pada periode tersebut adalah sebanyak 758 orang. Jumlah sampel yang digunakan dalam penelitian ini adalah sebanyak 262 orang yang ditentukan dengan rumus Slovin dengan tingkat kesalahan 5\%. Sampel dipilih dengan menggunakan metode Stratified Random Sampling dengan disiplin bidang ilmu sebagai basis stratifikasi, di mana $50 \%$ di antaranya berasal dari kelompok disiplin bidang ilmu Sains dan Teknologi (Saintek) dan 50\% lainnya berasal dari kelompok disiplin bidang ilmu Sosial, Ekonomi, dan Humaniora (Soshum). Adapun variabel respons yang digunakan dalam penelitian ini adalah lama waktu (hari) penyelesaian masa studi yang dihitung mulai dari tanggal awal masa perkuliahan sampai dengan tanggal responden (mahasiswa/i) tersebut diwisuda $(T)$. Sedangkan variabel prediktor yang digunakan adalah jenis kelamin $\left(\mathrm{X}_{1}\right)$ dan kelompok disiplin bidang ilmu $\left(\mathrm{X}_{2}\right)$. Selain itu, terdapat 3 variabel tambahan yang digunakan untuk menggambarkan karakteristik responden yaitu: zona asal sekolah, angkatan, dan predikat kelulusan.

Metode analisis statistik yang digunakan dalam penelitian ini adalah analisis survival model Cox Proportional Hazard (Cox PH). Analisis survival adalah suatu metode statistik yang digunakan untuk menganalisis data dengan variabel respons yang diperhatikan berupa waktu sampai terjadinya suatu kejadian (Kleinbaum \& Klein, 2012). Secara matematis model Cox $P H$ dapat ditulis dalam formulasi bentuk hazard pada Persamaan (1)

$h(t, \boldsymbol{X})=h_{0}(t) \exp \left(\sum_{i=1}^{p} \beta_{i} X_{i}\right)$

(1)

Di mana matriks $\boldsymbol{X}=\left(X_{1}, X_{2}, \ldots, X_{p}\right)$, merupakan kumpulan variabel penjelas dari 
Cox $P H$ model, $t$ merupakan variabel respons dan $\beta_{i}$ merupakan parameter model. Hazard rasio didefenisikan sebagai perbandingan nilai hazard dari dua buah kelompok dan secara matematis dapat ditulis pada Persamaan (2)

$\widehat{H R}=\frac{\widehat{h}\left(t_{i} X^{*}\right)}{\widehat{h}\left(t_{i}\right)}=\exp \left(\sum_{i=1}^{p} \widehat{\beta_{i}}\left(X_{i}^{*}-X_{i}\right)\right.$

Di mana matriks $\boldsymbol{X}^{*}$ merupakan kumpulan variabel penjelas pada kelompok pertama dan $\boldsymbol{X}$ merupakan kumpulan variabel penjelas pada kelompok kedua.

Tujuan penggunaan model Cox $P H$ adalah untuk mengetahui faktor yang memengaruhi lamanya waktu kelulusan mahasiswa/i Universitas Syiah Kuala berdasarkan jenis kelamin dan kelompok disiplin bidang ilmu yang dipelajari. Pengolahan data dilakukan dengan menggunakan software $R$ versi 3.5.0 dengan package survival.

Adapun langkah analisis yang dilakukan dalam penelitian ini adalah sebagai berikut:

1. Membangun Cox PH basemodel dengan memasukkan semua variabel prediktor (jenis kelamin dan kelompok disiplin bidang ilmu).

2. Proses seleksi variabel prediktor (variable selection) menggunakan metode backward elimination, yaitu dengan mengeluarkan variabel penjelas yang tidak dapat memenuhi pengujian secara serentak, parsial dan asumsi $P H$ pada tingkat signifikansi 5\% dari model.

3. Membangun model final dengan menggunakan variabel prediktor hasil proses variable selection pada langkah kedua.

4. Melakukan pengujian secara serentak, parsial, dan asumsi PH terhadap model final pada tingkat signifikansi 5\%.

Selain itu, metode Kaplan-Meier juga digunakan untuk menganalisis nilai fungsi survival berdasarkan jenis kelamin dan disiplin bidang ilmu yang dipelajari.

\section{HASIL DAN PEMBAHASAN}

\section{Karakteristik Dasar Sampel}

Karakteristik sampel dalam penelitian ini dapat dilihat berdasarkan zona wilayah asal sekolah SMA/MA/SMK sederajat, angkatan serta predikat responden pada saat kelulusan. Zona wilayah asal sekolah SMA/MA/SMK sederajat dibagi menjadi 7 kelompok, yang terdiri dari 6 wilayah di dalam Provinsi Aceh serta 1 wilayah di luar Provinsi Aceh. Pembagian wilayah di dalam Provinsi Aceh didasarkan pada pembagian zona berdasarkan roadmap Badan Perencanaan Pembangunan Daerah (Bappeda) Provinsi Aceh tahun 2015 sebagai berikut: 1) Zona Pusat: Kota Sabang, Banda Aceh, Kabupaten Aceh Besar dan Pidie, 2) Zona Utara: Kabupaten Pidie Jaya, Bireuen, Aceh Utara, Aceh Tengah dan Bener Meriah dan Kota Lhokseumawe, 3) Zona Timur: Kabupaten Aceh Timur, Aceh Tamiang dan Kota Langsa, 4) Zona Tenggara: Kabupaten Gayo Lues, Aceh Tenggara, Singkil dan Kota Subulussalam, 5) Zona Selatan: Kabupaten Aceh Selatan, Aceh Barat Daya dan Simeulue, dan 6) Zona Barat: Kabupaten Aceh Barat, Nagan Raya dan Aceh Jaya. Angkatan masuk responden dibagi menjadi 6 kelompok yaitu angkatan 2009, 2010, 2011, 2012, 2013 dan 2014. Sedangkan predikat kelulusan dibagi menjadi 3 kelompok yaitu Memuaskan, Sangat Memuaskan dan Pujian (Cumlaude). Tabel 1 menampilkan karakteristik sampel berdasarkan zona asal sekolah, angkatan serta predikat kelulusan untuk masing-masing variabel penjelas jenis kelamin dan kelompok disiplin ilmu.

Tabel 1 menunjukkan bahwa mahasiswa/i yang menjadi sampel dalam penelitian ini paling banyak berasal dari zona pusat yang terdiri dari Kota Sabang, Banda Aceh, Kabupaten Aceh Besar dan Pidie, baik jika dilihat berdasarkan jenis kelamin maupun disiplin bidang ilmu yang dipelajari. Hal ini dapat disebabkan karena zona pusat merupakan daerah yang berlokasi paling dekat dengan Universitas Syiah Kuala serta merupakan wilayah yang berbatasan 
langsung dengan ibu kota Provinsi Aceh sehingga lebih banyak mahasiswa/i yang berasal dari wilayah tersebut. Selanjutnya, angkatan dengan jumlah sampel mahasiswa/i yang paling banyak adalah angkatan 2012 . Hal ini disebabkan karena waktu pelaksanaan wisuda periode 2 tahun 2017 merupakan waktu kelulusan yang ideal bagi angkatan 2012 yang sudah menjalani masa perkuliahan antara 8 atau 9 semester. Tabel 1 juga menunjukkan bahwa lebih dari $75 \%$ lulusan pada saat wisuda periode 2 tahun 2017 tersebut memperoleh predikat kelulusan dengan kategori Sangat Memuaskan baik jika dilihat berdasarkan jenis kelamin maupun disiplin bidang ilmu yang dipelajari.

Tabel 1.

Karakteristik Dasar Sampel Berdasarkan Zona Asal Sekolah, Angkatan dan Predikat Kelulusan

\begin{tabular}{lrrrr}
\hline \multirow{2}{*}{ Variabel } & \multicolumn{2}{c}{ Jenis Kelamin } & \multicolumn{2}{c}{ Disiplin Ilmu } \\
\cline { 2 - 5 } & \multicolumn{1}{c}{ Laki-laki } & Perempuan & $\begin{array}{c}\text { Sosial, Ekonomi } \\
\text { dan Humaniora }\end{array}$ & $\begin{array}{r}\text { Sains dan } \\
\text { Teknologi }\end{array}$ \\
\hline Asal Sekolah & $12(4,6 \%)$ & $9(3,4 \%)$ & $12(4,6 \%)$ & $9(3,4 \%)$ \\
Zona Barat & $41(15,6 \%)$ & $69(26,3 \%)$ & $58(22,1 \%)$ & $52(19,8 \%)$ \\
Zona Pusat & $11(4,2 \%)$ & $15(5,7 \%)$ & $16(6,1 \%)$ & $10(3,8 \%)$ \\
Zona Selatan & $6(2,3 \%)$ & $9(3,4 \%)$ & $8(3,1 \%)$ & $7(2,7 \%)$ \\
Zona Tenggara & $6(2,3 \%)$ & $8(3,1 \%)$ & $5(1,9 \%)$ & $9(3,4 \%)$ \\
Zona Timur & $14(5,3 \%)$ & $29(11,1 \%)$ & $25(9,5 \%)$ & $18(6,9 \%)$ \\
Zona Utara & $14(5,3 \%)$ & $19(7,3 \%)$ & $7(2,7 \%)$ & $26(9,9 \%)$ \\
Luar Aceh & & & & \\
Angkatan & $3(1,1 \%)$ & $1(0,4 \%)$ & $4(1,5 \%)$ & $0(0,0 \%)$ \\
2009 & $25(9,5 \%)$ & $8(3,1 \%)$ & $18(6,9 \%)$ & $15(5,7 \%)$ \\
2010 & $21(8,0 \%)$ & $15(5,7 \%)$ & $29(11,1 \%)$ & $7(2,7 \%)$ \\
2011 & $44(16,8 \%)$ & $94(35,9 \%)$ & $75(28,6 \%)$ & $63(24,0 \%)$ \\
2012 & $11(4,2 \%)$ & $39(14,9 \%)$ & $5(1,9 \%)$ & $45(17,2 \%)$ \\
2013 & $0(0,0 \%)$ & $1(0,4 \%)$ & $0(0,0 \%)$ & $1(0,4 \%)$ \\
2014 & & & & \\
Predikat & $10(3,8 \%)$ & $3(1,1 \%)$ & $5(1,9 \%)$ & $8(3,1 \%)$ \\
Memuaskan & $87(33,2 \%)$ & $119(45,4 \%)$ & $94(35,9 \%)$ & $112(42,7 \%)$ \\
Sangat Memuaskan & $7(2,7 \%)$ & $36(13,7 \%)$ & $32(12,2 \%)$ & $11(4,2 \%)$ \\
Pujian (Cumlaude) & & &
\end{tabular}

\section{Deskripsi Lama Waktu Masa Studi}

Statistik deskriptif untuk lama masa studi berdasarkan jenis kelamin dan disiplin ilmu yang dipelajari dilihat berdasarkan rata-rata lama waktu kelulusan beserta 95\% selang kepercayaannya (confident interval), nilai standar deviasi dan median. Tabel 2 menampilkan beberapa statistik deskriptif penting dari data lama waktu kelulusan mahasiswa/i berdasarkan jenis kelamin dan disiplin ilmu yang dipelajari.
Tabel 2 menunjukkan bahwa secara rata-rata mahasiswa membutuhkan waktu sekitar 253 hari atau 8,4 bulan lebih lama untuk dapat menyelesaikan masa studi mereka dibandingkan dengan mahasiswi. Sedangkan disiplin bidang ilmu Saintek secara rata-rata dapat diselesaikan selama 238 hari $(7,9$ bulan) lebih cepat dari pada disiplin bidang ilmu Soshum. Selain berbeda secara nilai rata-rata, lama masa studi berdasarkan jenis kelamin dan disiplin bidang ilmu juga berbeda berdasarkan nilai tengah waktu kelulusannya. 
Tabel 2.

Statistik Deskriptif Lama Masa Studi Berdasarkan Jenis Kelamin dan Disiplin Ilmu yang Dipelajari

\begin{tabular}{lcccc}
\hline \multirow{2}{*}{ Statistik } & \multicolumn{2}{c}{ Jenis Kelamin } & \multicolumn{2}{c}{ Disiplin Ilmu } \\
\cline { 2 - 5 } & Laki-laki & \multirow{2}{*}{ Perempuan } & $\begin{array}{c}\text { Sosial, Ekonomi } \\
\text { dan Humaniora }\end{array}$ & $\begin{array}{c}\text { Sains dan } \\
\text { Teknologi }\end{array}$ \\
\hline Rata-rata & $1.901,63$ & $1.648,36$ & $1.867,95$ & $1.629,84$ \\
95\% CI Lower & $1.827,55$ & $1.602,33$ & $1.812,65$ & $1.570,31$ \\
95\% CI Upper & $1.975,72$ & $1.694,39$ & $1.923,25$ & $1.689,37$ \\
Standar Deviasi & 380,96 & 292,91 & 319,92 & 344,43 \\
Median & $1.690,00$ & $1.669,00$ & $1.674,00$ & $1.669,00$ \\
\hline
\end{tabular}

\section{Model Cox Proportional Hazard}

Variabel respons dalam analisis survival dapat berbentuk data tersensor maupun data tidak tersensor. Data dengan status tersensor dan tidak tersensor akan memengaruhi pembentukan model Cox $P H$. Dalam penelitian ini, data lama waktu penyelesaian masa studi di Universitas Syiah Kuala merupakan data yang tidak tersensor karena waktu awal dan waktu akhir masa studi dari semua responden diketahui. Untuk mendapatkan model yang baik, terdapat tiga pengujian statistik yang harus dilakukan terhadap sebuah Cox PH model.
Pertama, pengujian secara serentak melalui statistik Likelihood Ratio (LR) test. Kedua pengujian secara parsial melalui statistik Wald dan ketiga pengujian asumsi $\mathrm{PH}$ melalui statistik Chi-square. Model Cox PH yang baik adalah model yang dapat memenuhi ketiga pengujian statistik tersebut. Variabel prediktor yang tidak dapat memenuhi dua asumsi pertama akan dikeluarkan dari model dan akan dilakukan stratifikasi apabila tidak dapat memenuhi asumsi yang ketiga. Hal ini dilakukan untuk mendapatkan variabel prediktor yang benarbenar signifikan dalam Cox PH model.

Tabel 3.

Cox PH Basemodel dan Pengujian Asumsi PH

\begin{tabular}{|c|c|c|c|c|c|c|c|}
\hline \multirow{2}{*}{ Variabel } & \multirow{2}{*}{ Keterangan } & \multicolumn{4}{|c|}{$\begin{array}{l}\text { Pengujian parsial } \\
\text { model }\end{array}$} & \multicolumn{2}{|c|}{ Pengujian asumsi $P H$} \\
\hline & & Beta & Hazard & Wald & $p$ & Chi-square & $p$ \\
\hline \multirow[t]{2}{*}{$\mathrm{X}_{1}$} & $\begin{array}{l}\text { Jenis Kelamin } \\
\text { 1: Laki-laki (R) }\end{array}$ & & & & & & \\
\hline & 2: Perempuan & 0,806 & 2,240 & 6,08 & $<0,001^{* *}$ & 2,71 & 0,100 \\
\hline \multirow[t]{3}{*}{$\mathrm{X}_{2}$} & Disiplin Ilmu & & & & & & \\
\hline & $\begin{array}{l}\text { 1: Sosial, ekonomi } \\
\text { dan humaniora }(\mathrm{R})\end{array}$ & & & & & & \\
\hline & 2: Sains dan teknologi & 0,525 & 1,690 & 4,15 & $<0,001^{* *}$ & 7,02 & $0,008^{* *}$ \\
\hline \multicolumn{8}{|c|}{ Likelihood ratio $\left(\right.$ LR) test $=54,3 ; p<0,001^{* *} ;(\mathrm{R})$ : Reference kategori } \\
\hline
\end{tabular}

Tabel 3 menampilkan beberapa statistik penting berupa nilai Beta, Hazard, Wald, LR test dan $p$ dari Cox PH basemodel yang terdiri atas semua variabel prediktor yang

digunakan dalam penelitian ini (jenis kelamin dan disiplin bidang ilmu).
Tabel 3 juga menunjukkan bahwa uji serentak melalui LR test untuk Cox $\mathrm{PH}$ basemodel tersebut adalah signifikan dengan nilai likelihood ratio test sebesar 54,3 dengan $p<0,001$. Selanjutnya, kedua variabel prediktor, jenis kelamin dan disiplin bidang ilmu tersebut juga signifikan secara parsial melalui statistik Wald yang ditandai oleh nilai $p<0,001$. Selain pengujian secara 
serentak dan parsial, Cox $P H$ model tersebut juga perlu dilakukan pengujian mengenai asumsi Proportional Hazard (PH) yang mensyaratkan bahwa nilai hazard rasio untuk variabel prediktor tersebut bernilai konstan dan independen terhadap waktu. Sebuah variabel prediktor dikatakan memenuhi asumsi $P H$ apabila memiliki nilai statistik Chi-square yang tidak signifikan pada $\alpha=$ 0,05 . Berdasarkan Tabel 3, terlihat bahwa variabel prediktor jenis kelamin (Perempuan) dan disiplin bidang ilmu (Saintek) dalam Cox $\mathrm{PH}$ basemodel masing-masing memiliki nilai Chi-square sebesar 2,71 dan 7,02 dengan nilai $p$ sebesar 0,100 untuk variabel jenis kelamin (Perempuan) dan 0,008 untuk variabel disiplin bidang ilmu (Saintek). Sehingga dapat disimpulkan bahwa hanya variabel prediktor jenis kelamin saja yang telah memenuhi asumsi $P H$. Sedangkan variabel prediktor disiplin bidang ilmu tidak dapat memenuhi asumsi $P H$. Dengan demikian, variabel disiplin bidang ilmu perlu distratifikasi sehingga membentuk Stratified Cox model sebagai upaya pemenuhan asumsi PH tersebut. Menurut Abdelaal \& Zakria (2015), Stratified Cox model adalah modifikasi dari model regresi Cox terhadap variabel prediktor yang tidak memenuhi asumsi $P H$. Prediktor yang tidak memenuhi asumsi $P H$ tersebut disesuaikan dengan proses stratifikasi (Abadi dkk., 2014). Stratified Cox model hanya terdiri dari variabel prediktor yang memenuhi asumsi $\mathrm{PH}$, sedangkan variabel prediktor yang telah distratifikasi tidak dimasukkan ke dalam model (Gonzalez dkk., 2013). Hasil pembentukan dan pengujian Stratified Cox model dapat dilihat pada Tabel 4.

Tabel 4.

Stratified Cox Model dan Pengujian Asumsi PH

Pengujian parsial

Variabel Keterangan model

Pengujian asumsi $\boldsymbol{P H}$

Beta Hazard Wald $p$

Chi-square

$p$

$\mathrm{X}_{1} \quad$ Jenis Kelamin

1: Laki-laki (R)

2: Perempuan $\quad 0,813 \quad 2,255 \quad 6,11<0.001^{* *}$

2,68

0,102

Likelihood ratio $\left(\right.$ LR) test $=38,6 ; p<0,001^{* *} ;(\mathrm{R})$ : Reference kategori

Uji serentak melalui LR test untuk Stratified Cox model final tersebut adalah signifikan dengan nilai likelihood ratio test sebesar 38,6 dengan $p<0,001$. Selanjutnya, variabel prediktor jenis kelamin (Perempuan) tersebut juga signifikan secara parsial melalui statistik Wald yang ditandai oleh nilai $p<$ 0,001 . Selain itu, model tersebut juga sudah memenuhi pengujian asumsi $P H$ dengan nilai Chi-square sebesar 2,68 dengan nilai $p$ sebesar 0,102. Sehingga dapat disimpulkan bahwa Stratified Cox model tersebut telah memenuhi semua persyaratan sebagai model yang baik.

Interpretasi nilai hazard rasio menunjukkan bahwa penyelesaian masa studi pada program Strata 1 di Universitas Syiah Kuala untuk kelompok mahasiswi cenderung mengalami peningkatan potensi sebesar $(2,255-1)=125,5 \%$ untuk lebih cepat selesai dibandingkan dengan masa studi untuk kelompok mahasiswa dengan stratifikasi kelompok disiplin bidang ilmu yang dipelajari.

Sistem pendidikan di perguruan tinggi berbeda dengan pendidikan dasar dan menengah. Kelulusan peserta didik yang mengenyam pendidikan dasar dan menengah sangat dipengaruhi oleh durasi waktu yang telah ditentukan, misalnya SD selama enam tahun, SMP selama tiga tahun dan SMA selama tiga tahun. Sedangkan kelulusan seorang mahasiswa/i di perguruan tinggi dipengaruhi oleh berbagai faktor. Ihsan \& Zaki (2015) menyimpulkan bahwa terdapat 4 kelompok faktor yang memengaruhi lama 
studi mahasiswa/i yaitu faktor internal dan pembelajaran, faktor kesiapan dan potensi diri, faktor ekonomi dan manajemen kampus serta faktor eksternal lingkungan masyarakat. Fitriana (2016) menyatakan bahwa lama studi mahasiswa/i di Jurusan Pendidikan Matematika Universitas Negeri Semarang dipengaruhi oleh faktor Indeks Prestasi Akademik (IPK). Ariani, Sumarjaya, \& Oka (2013) menyatakan bahwa faktor lain yang memengaruhi lama waktu kelulusan terutama untuk mahasiswa/i dengan IPK kategori sangat memuaskan adalah jenis kelamin, jurusan, daerah asal, dan lama pengerjaan tugas akhir. Lebih spesifik, Rusmawati, Tripalupi, \& Artana (2014) menyimpulkan bahwa faktor internal berupa kecerdasan, minat dan bakat juga memengaruhi masa studi mahasiswa/i di Jurusan Pendidikan Ekonomi Universitas Pendidikan Ganesha. Hal ini juga sejalan dengan hasil penelitian yang dilakukan oleh Pratiwi, Handoyo, \& Murtinugraha (2016) terhadap mahasiswa/i Jurusan Pendidikan Teknik Bangunan Universitas Negeri Jakarta yang menyimpulkan bahwa faktor bakat dan kecerdasan merupakan faktor internal yang paling memengaruhi masa studi mahasiswa/i. Ketidakmampuan mahasiswa/i untuk mengambil kesempatan dan mengatur waktu dengan baik dalam menyelesaikan studinya juga merupakan faktor penyebab keterlambatan penyelesaian studi di Jurusan Pendidikan Geografi Fakultas Ilmu Sosial Universitas Negeri Padang (Buansah, 2018). Selain itu, staf pengajar (guru) di tingkat pendidikan dasar dan menengah berperan besar dalam keberhasilan proses belajar mengajar. Sedangkan di perguruan tinggi, mahasiswa/i akan berperan lebih dominan untuk menentukan keberhasilan dalam proses pendidikan mereka. Staf pengajar (dosen) di perguruan tinggi hanya bertindak sebagai stimulator. Dengan demikian, mahasiswa/i yang mampu menyelesaikan studi dengan waktu yang lebih cepat dianggap memiliki tingkat kecerdasan atau kemampuan beradaptasi yang lebih baik dari pada mahasiswa/i yang membutuhkan waktu yang lebih lama dalam menyelesaikan pendidikan mereka.

Meskipun mahasiswi memiliki tingkat kecemasan pra-ujian yang lebih tinggi (Chapell dkk., 2005), namun prestasi akademik mereka jauh lebih baik dari pada mahasiswa. Penelitian dari Djudin (2018) terhadap 620 mahasiswa jurusan Pendidikan MIPA FKIP di Universitas Tanjungpura Pontianak menunjukkan bahwa terdapat hubungan negatif yang kuat dan signifikan antara prestasi akademik dan lama masa studi. Semakin tinggi prestasi akademik seorang individu maka akan semakin pendek lama masa studi individu tersebut. Mitsos dan Browne (1998) menyatakan bahwa perempuan lebih baik dari pada laki-laki dalam proses belajar karena mereka menghabiskan lebih banyak waktu untuk mengerjakan tugas, lebih terorganisir, dan lebih baik dalam memenuhi tenggat waktu yang diberikan. Penelitian yang dilakukan oleh Anwar dkk., (2017) terhadap 105 mahasiswa/i Universitas Syiah Kuala menunjukkan bahwa lebih banyak mahasiswi yang mengunjungi perpustakaan untuk mengerjakan tugas perkuliahan dari pada mahasiswa dengan perbandingan $69,52 \%$ berbanding 30,48\%. Hal ini dapat menjelaskan mengapa mahasiswi dapat menyelesaikan studi lebih cepat jika dibandingkan dengan mahasiswa.

Lebih lanjut, Stratified Cox model tersebut dapat dipisahkan menjadi 2 model berdasarkan kelompok disiplin bidang ilmu yang dipelajari. Tabel 5 menampilkan pembagian Stratified Cox model berdasarkan disiplin bidang ilmu tersebut.

Berdasarkan kriteria nilai $p$, baik untuk uji serentak melalui LR test maupun uji parsial melalui statistik Wald, dapat disimpulkan bahwa kedua model tersebut telah memenuhi kriteria pengujian secara serentak dan parsial yang ditandai dengan nilai $p<0,001$ untuk masing-masing uji LR test dan wald pada kedua model tersebut. Model pertama untuk disiplin bidang ilmu Soshum menunjukkan 
bahwa kelompok mahasiswi cenderung mengalami peningkatan potensi sebesar $(2,270-1)=127,0 \%$ untuk lebih cepat selesai dibandingkan dengan masa studi untuk kelompok mahasiswa pada kelompok disiplin bidang ilmu tersebut. Sedangkan melalui model kedua, terlihat bahwa kelompok mahasiswi cenderung mengalami peningkatan potensi sebesar $(2,239-1)=$ $123,9 \%$ untuk lebih cepat selesai dibandingkan dengan masa studi untuk kelompok mahasiswa pada kelompok disiplin bidang ilmu Saintek. Temuan ini sejalan dengan hasil penelitian yang dilakukan oleh Asmita (2007), di mana tingkat motivasi belajar pada mahasiswi lebih baik dari pada motivasi belajar pada mahasiswa, meskipun pada penelitian tersebut perbedaan hasil skor penelitian antara kelompok mahasiswa dan mahasiswi tidak signifikan. Di sisi lain, hasil penelitian Atmoko (2010) menunjukkan bahwa lakilaki memperoleh skor human capital skill yang lebih tinggi daripada perempuan, namun perolehan skor prestasi belajar lakilaki lebih rendah dari pada perempuan. Penelitian lain dari Trinovryan, Azlina, \& Silfi (2016) terhadap 120 orang mahasiswa yang berasal dari tiga universitas yaitu Universitas Riau, Universitas Islam Riau, dan Universitas Islam Negeri Sultan Syarif Qasim II menyimpulkan bahwa laki-laki dan perempuan memiliki tingkat kecerdasan emosional dan spiritual yang berbeda. Tidak hanya dalam dunia pendidikan, kecerdasan emosional juga berpengaruh signifikan terhadap kinerja seseorang (Ristami, 2013).

Tabel 5.

Stratified Cox Model Berdasarkan Disiplin Bidang Ilmu

\begin{tabular}{|c|c|c|c|c|c|c|}
\hline \multirow{2}{*}{ Disiplin Ilmu } & \multirow{2}{*}{ Variabel } & \multirow{2}{*}{ Keterangan } & \multicolumn{4}{|c|}{ Pengujian Parsial Model } \\
\hline & & & Beta & Hazard & Wald & $p$ \\
\hline $\begin{array}{l}\text { Sosial, Ekonomi } \\
\text { dan Humaniora }{ }^{a}\end{array}$ & $\mathrm{X}_{1(1)}$ & $\begin{array}{l}\text { Jenis Kelamin } \\
\text { 1: Laki-laki (R) }\end{array}$ & & & & \\
\hline $\begin{array}{l}\text { Sains dan } \\
\text { Teknologi }{ }^{b}\end{array}$ & $\mathrm{X}_{1(2)}$ & $\begin{array}{l}\text { 2: Perempuan } \\
\text { Jenis Kelamin } \\
\text { 1: Laki-laki (R) }\end{array}$ & 0,820 & 2,270 & 4,49 & $<0,001^{* *}$ \\
\hline & & 2: Perempuan & 0,806 & 2,239 & 4,15 & $<0,001^{* *}$ \\
\hline
\end{tabular}

Adanya perbedaan antara laki-laki dan perempuan dapat dijelaskan dalam berbagai aspek psikologis melalui beberapa penelitian. Salah satu di antaranya dilakukan oleh Brizendine (2006), seorang ahli neuropsikiatri dan direktur klinik yang khusus mengkaji fungsi otak perempuan. Brizendine menjelaskan bahwa secara struktur terdapat perbedaan antara otak lakilaki dan perempuan, hal ini berakibat pada perbedaan keduanya yang berkaitan dengan sisi intelektualitas, baik cara berpikir, persepsi, cara berkomunikasi, dan lain sebagainya. Pendidikan dan psikologi kognitif telah menunjukkan bahwa penggunaan konsep memori kerja (working memory) sebagai kerangka teori telah membantu dalam memahami bagaimana peserta didik berpikir, belajar dan mengingat informasi (Fenesi, Sana, Kim, \& Shore, 2015). Bevilacqua (2017) menyatakan bahwa teori muatan kognitif harus mempertimbangkan adanya perbedaan fisik dan psikologis berdasarkan jenis kelamin seseorang pada bagian mata, otak, dan memori kerja (working memory) yang memengaruhi beban kognitif antara laki-laki dan perempuan dalam memandang dan menyimpan informasi dalam proses pembelajaran.

Penelitian lain yang menunjukkan adanya perbedaan antara laki-laki dan perempuan juga dilakukan oleh Aziz dan Mangestuti (2006) pada 304 mahasiswa/i dan ditemukan bahwa perempuan memiliki tingkat 
kecerdasan yang lebih tinggi dibanding lakilaki yang diukur dengan tes Standard Progressive Matrices (SPM) dengan perbandingan nilai rata-rata 166,80 : 127,28. Hasil yang sama juga ditemukan oleh Aziz (2006) melalui penelitian yang dilakukannya pada 82 orang anak dan diperoleh hasil bahwa jumlah anak perempuan yang memiliki kreativitas yang tinggi lebih banyak dibanding laki-laki dengan perbandingan 35 orang $(53 \%)$ berbanding 31 orang (47\%). Silvia (2015) menyatakan bahwa kecerdasan dan kreativitas memiliki hubungan yang lebih erat daripada teori yang berkembang selama ini. Menurut Priambodo, Listiara, \& Astuti (2013), salah satu faktor yang dapat membangun kreativitas adalah kebebasan psikologi. Cramond, Matthews-Morgan, Bandalos, dan Zuo (2005) menyatakan adanya hubungan antara perbedaan jenis kelamin dengan berbagai aspek. Hal ini terlihat dari hasil analisis mereka terhadap jurnal penelitian dari tahun 1958 sampai 1998. Mereka menemukan adanya perbedaan baik pada aspek fluency, flexibility, originality, dan elaboration, dimana perempuan cenderung lebih tinggi dibandingkan laki-laki.

\section{Analisis Nilai Fungsi Survival Kaplan- Meier}

Selain melalui analisis Cox $\mathrm{PH}$ model, data lama waktu kelulusan mahasiswa/i tersebut juga dianalisis dengan melihat nilai fungsi survival melalui pendekatan non-parametrik metode Kaplan-Meier. Perbedaan nilai survival tersebut diuji dengan menggunakan uji Log rank test dengan tingkat signifikansi 5\%. Gambar 1 dan 2 menampilkan visualisasi nilai fungsi survival dengan metode Kaplan-Meier berdasarkan variabel jenis kelamin dan kelompok disiplin bidang ilmu yang dipelajari.

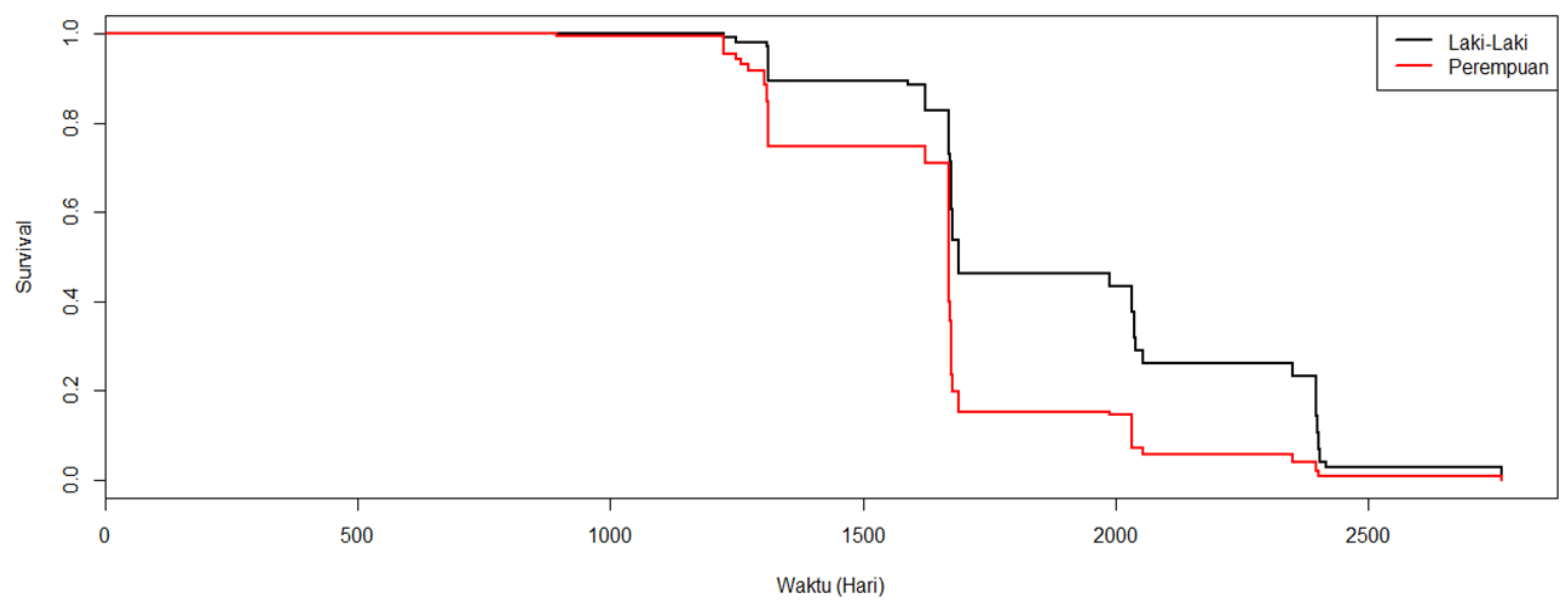

Gambar 1. Estimasi Nilai Fungsi Survival Berdasarkan Jenis Kelamin dengan Metode Kaplan-Meier

Nilai fungsi survival menunjukkan besaran peluang seorang mahasiswa/i masih berada dalam masa studi atau belum menyelesaikan studinya pada titik waktu $t$ tertentu. Berdasarkan Gambar 1, terlihat bahwa nilai fungsi survival berdasarkan jenis kelamin merupakan sebuah fungsi tangga dengan tren menurun. Secara teori, nilai fungsi survival pada awal pengamatan adalah bernilai 1 dan pada akhir pengamatan bernilai 0 . Dengan demikian, peluang seorang mahasiswa/i untuk tetap dalam masa studi akan semakin kecil seiring bertambah lamanya masa studi yang telah dijalani oleh mahasiswa/i yang bersangkutan. Lebih detail, mahasiswi memiliki nilai fungsi survival yang lebih kecil daripada mahasiswa di semua titik pengamatan. Hal ini menunjukkan bahwa mahasiswi berpotensi lebih cepat dalam menyelesaikan masa studi mereka dibandingkan dengan mahasiswa. Perbedaan nilai survival antara kelompok mahasiswa 
dan mahasiswi tersebut adalah signifikan Chi-square sebesar 37,0 dan $p<0,001$. berdasarkan uji Log rank test dengan nilai

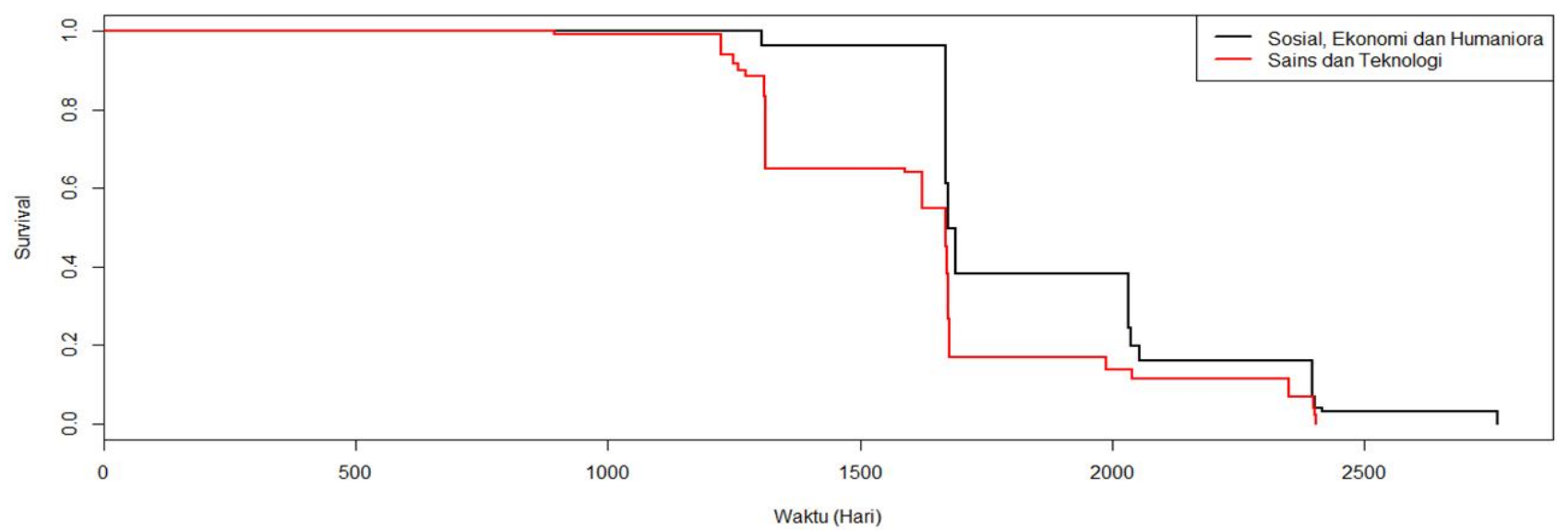

Gambar 2. Estimasi Nilai Fungsi Survival Berdasarkan Disiplin Ilmu dengan Metode Kaplan-Meier

Sama halnya dengan nilai fungsi survival berdasarkan jenis kelamin, nilai fungsi survival berdasarkan disiplin bidang ilmu yang dipelajari juga menunjukkan fungsi tangga dengan tren yang menurun baik untuk kelompok bidang ilmu Soshum maupun kelompok Saintek sebagaimana terlihat pada Gambar 2. Dengan demikian, peluang seorang mahasiswa/i yang mengambil kedua disiplin bidang ilmu tersebut untuk tetap berada dalam masa studi akan semakin kecil seiring bertambah lamanya masa studi mahasiswa/i yang bersangkutan. Mahasiswa/i yang mempelajari bidang ilmu Saintek memiliki nilai fungsi survival yang lebih kecil dari pada mereka yang mempelajari bidang Soshum pada semua titik pengamatan. Dengan kata lain, mahasiswa/i yang mempelajari bidang ilmu Saintek cenderung untuk lulus lebih cepat dari pada mereka yang mempelajari bidang ilmu Soshum. Perbedaan nilai survival antara kedua disiplin bidang ilmu tersebut juga signifikan berdasarkan uji Log rank test dengan nilai Chi-square sebesar 21,2 dan $p<$ 0,001 .

Gambar 3 menunjukkan perbandingan nilai fungsi survival untuk 4 kelompok mahasiswa/i yang merupakan kombinasi dari kategori jenis kelamin dan kelompok disiplin bidang ilmu yang dipelajari. Keempat kelompok tersebut adalah kelompok laki-laki bidang ilmu Soshum, kelompok perempuan bidang ilmu Soshum, kelompok laki-laki bidang ilmu Saintek dan terakhir kelompok perempuan bidang ilmu Saintek.

Secara umum, nilai fungsi survival untuk keempat kelompok tersebut adalah menurun dengan bentuk fungsi tangga. Sebagai catatan, terlihat bahwa nilai fungsi survival beberapa kelompok adalah sama atau sangat mendekati satu dengan yang lainnya di beberapa titik pengamatan. Akan tetapi, secara umum terlihat bahwa kelompok yang memiliki nilai fungsi survival yang paling besar adalah kelompok mahasiswa yang mempelajari disiplin bidang ilmu Soshum. Kelompok dengan urutan nilai fungsi survival terbesar selanjutnya adalah kelompok mahasiswa yang mempelajari disiplin bidang ilmu Saintek, kemudian kelompok mahasiswi dari bidang ilmu Soshum. Sedangkan kelompok mahasiswi yang mempelajari disiplin bidang ilmu Saintek merupakan kelompok yang memiliki nilai fungsi survival yang paling kecil pada semua titik waktu pengamatan. 


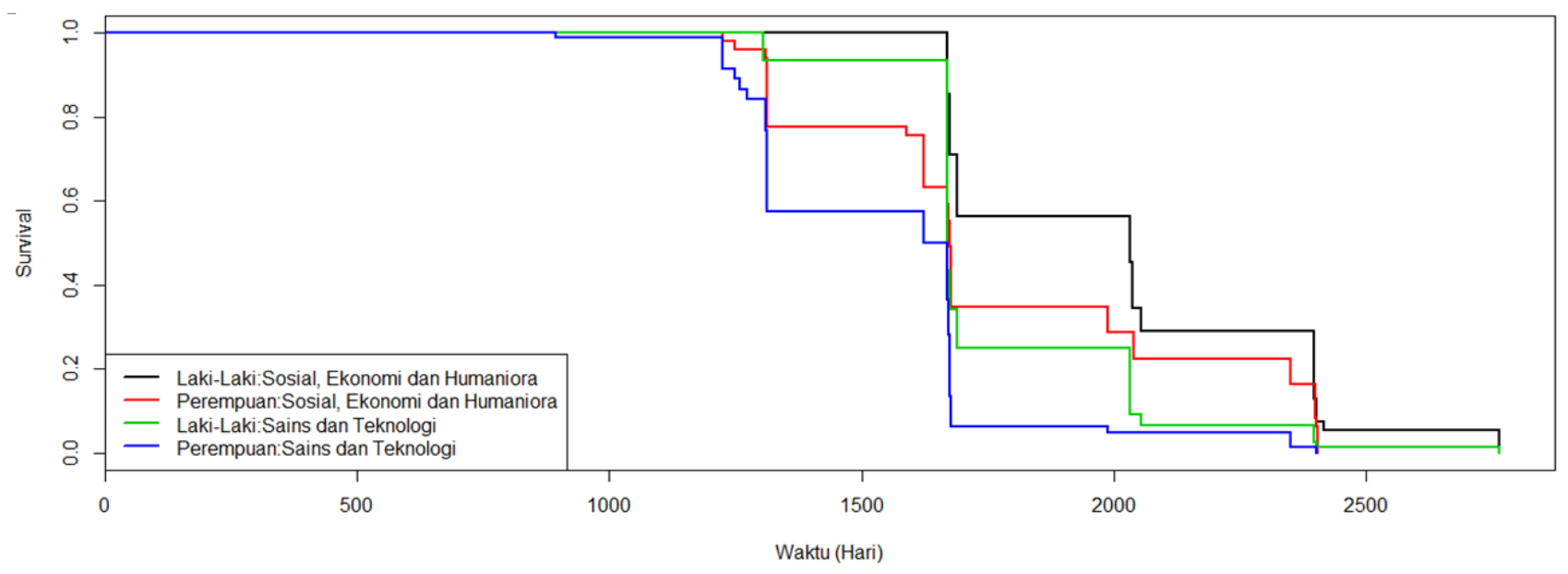

Gambar 3. Estimasi Nilai Fungsi Survival Berdasarkan Jenis Kelamin dan Disiplin Ilmu dengan Metode Kaplan-Meier

Dengan demikian, dapat disimpulkan bahwa kelompok yang memiliki peluang untuk lulus dengan urutan mulai dari yang paling cepat adalah kelompok mahasiswi Saintek, kelompok mahasiswi Soshum, kelompok mahasiswa Saintek dan terakhir adalah kelompok mahasiswa Soshum. Perbedaan nilai fungsi survival keempat kelompok tersebut adalah signifikan yang dibuktikan melalui uji Log rank test dengan nilai $p<$ 0,001 dan Chi-square sebesar 38,8.

Meskipun perempuan yang mempelajari disiplin bidang ilmu Saintek berpeluang lebih besar untuk lulus lebih cepat, penelitian Wang dan Degol (2017) menunjukkan bahwa perempuan yang berkarir dalam bidang sains, teknologi dan matematika masih kurang terwakili jika dibandingkan dengan laki-laki. Hal yang sama juga dilaporkan oleh National Science Foundation (2011). Kurangnya keterwakilan perempuan tersebut disebabkan oleh 6 hal yaitu: kemampuan kognitif, kekuatan kognitif relatif, minat atau preferensi pekerjaan, gaya hidup atau preferensi keseimbangan kerja-keluarga, kemampuan khusus di lapangan, dan stereotip serta bias terkait gender (Wang \& Degol, 2017).

Kecenderungan mahasiswa lebih lama dalam menyelesaikan studi mereka juga dapat disebabkan oleh sikap menunda studi (prokrastinasi). Penelitian Rahmandani (2017) terhadap 127 mahasiswa/i program sarjana reguler, Jurusan Ilmu Gizi, Fakultas Kedokteran, Universitas Diponegoro menunjukkan bahwa prokrastinasi secara langsung berdampak pada penurunan prestasi akademik. Menurut hasil penelitian Huda (2012), persentase mahasiswa yang menunda studi adalah sebesar 78,5\%, sedangkan mahasiswi yang menunda studinya adalah sebesar 21,5\%. Hal ini sejalan dengan penelitian Balkis dan Duru (2017) terhadap 441 orang mahasiswa/i yang menyimpulkan bahwa mahasiswa memiliki tingkat prokrastinasi akademik yang lebih tinggi dengan prestasi dan kepuasan akademik yang lebih rendah jika dibandingkan dengan mahasiswi. Kedua penelitian tersebut menunjukkan bahwa mahasiswa cenderung lebih sering menunda studi mereka dibandingkan dengan mahasiswi. Prokrastinasi dapat disebabkan oleh berbagai hal, salah satunya adalah tingkat stres (Adlina \& Amna, 2016). Menurut Rahmandani (2017), prokrastinasi akademik juga berhubungan negatif dengan tingkat pemaafan diri. Dengan kata lain, semakin tinggi tingkat pemaafan diri, maka akan semakin rendah prokrastinasi akademik, dan sebaliknya.

Pada akhirnya, berdasarkan hasil penelitian, analisa dan uraian di atas maka dapat disimpulkan bahwa perempuan cenderung memiliki tingkat kecerdasan yang lebih tinggi jika dibandingkan dengan laki-laki terutama dalam proses pembelajaran di 
perguruan tinggi serta dalam hal penguasaan ilmu pengetahuan.

\section{SIMPULAN}

Penelitian ini memberikan alternatif metode penilaian terhadap perbandingan tingkat kecerdasan antara laki-laki dan perempuan terutama dalam proses pembelajaran di perguruan tinggi serta dalam bidang penguasaan ilmu pengetahuan. Berdasarkan hasil penelitian, diketahui bahwa mahasiswi (perempuan) cenderung memiliki potensi $125,5 \%$ untuk lebih cepat dalam menyelesaikan masa studi dibandingkan dengan mahasiswa (laki-laki). Jika ditinjau berdasarkan disiplin bidang ilmu yang dipelajari, mahasiswi memiliki potensi $127 \%$ untuk lebih cepat dalam menyelesaikan masa studinya dibandingkan dengan mahasiswa untuk disiplin bidang ilmu Sosial, Ekonomi dan Humaniora (Soshum) dan 123,9\% untuk disiplin bidang ilmu Sains dan Teknologi (Saintek). Selanjutnya, berdasarkan analisis nilai fungsi survival dengan metode KaplanMeier juga terlihat bahwa mahasiswi (perempuan) memiliki peluang yang lebih besar untuk dapat menyelesaikan masa studi lebih awal dari pada mahasiswa (laki-laki). Selain itu, mahasiswa/i yang memilih disiplin bidang ilmu Saintek berpeluang lebih besar untuk lulus lebih awal dari pada mereka yang memilih disiplin bidang ilmu Soshum. Sehingga dapat disimpulkan bahwa perempuan memiliki tingkat kecerdasan yang lebih tinggi dari pada laki-laki terutama dalam proses pembelajaran di perguruan tinggi serta dalam penguasaan ilmu pengetahuan.

\section{DAFTAR PUSTAKA}

Abadi, A., Yavari, P., Dehghani-Arani, M., Alavi-Majd, H., Ghasemi, E., Amanpour, F., \& Bajdik, C. (2014). Cox models survival analysis based on breast cancer treatments. Iranian Journal of Cancer Prevention, 7(3), 124-129.
Abdelaal, M. M. A., \& Zakria, S. H. E. A. (2015). Modeling survival data by using cox regression model. American Journal of Theoretical and Applied Statistics, 4(6), 504-512.

Adlina, N., \& Amna, Z. (2016). Hubungan antara stres dengan prokrastinasi pada mahasiswa yang sedang menyusun skripsi di Universitas Syiah Kuala. Jurnal Ilmiah Mahasiswa Psikologi, 1(3), 62-70.

Anwar, S., Afriyani, A., Ula, P. S., Safriana, I., Fajri, I., \& Ariska, R. (2017). Visitor behavior in the library of Syiah Kuala University based on their visiting time duration. Eksakta: Jurnal Ilmu-ilmu MIPA, 17(2), 119-136.

Ariani, N. K. D., Sumarjaya, I. W., \& Oka, T. B. (2013). Analisis faktor-faktor yang memengaruhi waktu kelulusan mahasiswa dengan menggunakan metode gompit (studi kasus: mahasiswa Fakultas MIPA Universitas Udayana). E-Jurnal Matematika, 2(3), 40-45.

Asmita, S. H. (2007). Motivasi belajar ditinjau dari perbedaan jenis kelamin dan status mahasiswa di Universitas Islam Negeri Malang (Undergraduate thesis, Universitas Islam Negeri Malang, Malang, Indonesia).

Atmoko, D. (2010). Perbedaan human capital skill dan prestasi belajar mahasiswa berdasarkan jenis kelamin dan intelegensi (Undergraduate thesis, Universitas Islam Negeri Syarif Hidayatullah, Jakarta, Indonesia).

Aziz, R. (2006). Studi deskriptif tentang kreativitas siswa sekolah menengah pertama di kota Malang. Psikoislamika, 3(2), 1-12.

Aziz, R., \& Mangestuti, R. (2006). Tiga jenis kecerdasan dan agresivitas mahasiswa. 
Psikologika: Jurnal Pemikiran dan Penelitian Psikologi, 11(21), 64-77.

Azwar, S. (2012). Metode penelitian. Yogyakarta: Pustaka Pelajar.

Balkis, M., \& Duru, E. (2017). Gender differences in the relationship between academic procrastination, satifaction with academic life and academic performance. Electronic Journal of Research in Educational Psychology, 15(1), 105-125.

Bevilacqua, A. (2017). Commentary: Should gender differences be included in the evolutionary upgrade to cognitive load theory? Educational Psychology Review, 29(1), 189-194.

Brizendine, L. (2006). The female brain (1 ed.). New York, NY: Morgan Road Books.

Buansah, A. (2018). Faktor-faktor keterlambatan studi mahasiswa pendidikan geografi Fakultas Ilmu Sosial Universitas Negeri Padang. Jurnal Buana, 2(2), 518-530.

Chapell, M. S., Blanding, Z. B., Silverstein, M. E., Takahashi, M., Newman, B., Gubi, A., \& McCann, N. (2005). Test anxiety and academic performance in undergraduate and graduate students. Journal of Educational Psychology, 97(2), 268-274.

Cramond, B., Matthews-Morgan, J., Bandalos, D., \& Zuo, L. (2005). A Report on the 40-year follow-up of the torrance tests of creative thinking: Alive and well in the new millennium. Gifted Child Quarterly, 49(4), 283291.

Djudin, T. (2018). Analisis prestasi akademik mahasiswa lulusan Jurusan Pendidikan MIPA FKIP UNTAN ditinjau dari jalur masuk (SNMPTN,
SBMPTN, Mandiri) dan program kuliah (S-1 Reguler, S-1 Percepatan APK). Jurnal Pendidikan Matematika dan IPA, 9(2), 76-89.

Fenesi, B., Sana, F., Kim, J. A., \& Shore, D. I. (2015). Reconceptualizing working memory in educational research. Educational Psychology Review, 27(2), 333-351.

Fitriana, R. (2016). Analisis survival faktorfaktor yang mempengaruhi lama studi mahasiswa pendidikan matematika angkatan 2010 dengan metode regresi cox proportional hazard (Undergraduate thesis, Universitas Negeri Semarang, Semarang, Indonesia).

Gonzalez, C. V., Dupuy, J. F., López, M. F., Luaces, P. L., Rodríguez, C. R., Marinello, G. G., ... Ramos, T. C. (2013). Stratified cox regression analysis of survival under CIMAvax ${ }^{\circledR}$ EGF Vaccine. Journal of Cancer Therapy, 4(8A), 8-14.

Goriounova, N. A., Heyer, D. B., Wilbers, R., Verhoog, M. B., Giugliano, M., Verbist, C., ... Mansvelder, H. D. (2018). Large and fast human pyramidal neurons associate with intelligence. ELife, 7, 1-38.

Huda, M. J. N. (2012). Perbedaan prokrastinasi akademik berdasarkan jenis kelamin di UIN Sunan Kalijaga Yogyakarta. PALASTRèN, 4(2), 119131.

Ihsan, H., \& Zaki, A. (2015). Analisa faktorfaktor yang menghambat penyelesaian studi mahasiswa FMIPA UNM. Jurnal Scientific Pinisi, 1(1), 25-33.

Jaušovec, N., \& Pahor, A. (2017). Increasing intelligence. London: Academic Press.

Khaterina, \& Garliah, L. (2012). Perbedaan 
kecerdasan emosi pada pria dan wanita yang mempelajari dan yang tidak mempelajari alat musik piano. Predicara, 1(1), 17-20.

Khodijah, N. (2014). Psikologi pendidikan. Jakarta: Raja Grafindo Persada.

Kleinbaum, D. G., \& Klein, M. (2012). Survival analysis: A self-learning text (3 ed.). New York, NY: Springer Science Business Media, Inc.

Mitsos, E., \& Browne, K. (1998). Gender differences in education: The underachievement of boys. Sociology Review, 8(1), 27-31.

National Science Foundation. (2011). Women, minorities, and persons with disabilities in science and engineering: 2011. Arlington, TX: National Science Foundation.

Pakkenberg, B., \& Gundersen, H. J. G. (1997). Neocortical neuron number in humans: Effect of sex and age. The Journal of Comparative Neurology, 384(2), 312-320.

Petersen, J. (2018). Gender difference in verbal performance: A meta-analysis of United States state performance assessments. Educational Psychology Review, 30(4), 1269-1281.

Pratiwi, D. A., Handoyo, S. S., \& Murtinugraha, R. E. (2016). Faktorfaktor yang mempengaruhi masa studi mahasiswa pendidikan teknik bangunan Universitas Negeri Jakarta. Jurnal Pendidikan Teknik Sipil, 5(2), $1-10$.

Priambodo, B., Listiara, A., \& Astuti, T. P. (2013). Pengaruh dari problem posing method terhadap kreativitas verbal siswa SMP Kelas VII. Jurnal Psikologi Universitas Diponegoro, 12(2), 109 120.
Rahmandani, A. (2017). Pemaafan dan prokrastinasi akademik mahasiswa. Jurnal Psikologi Undip, 16(1), 64-76.

Ristami, K. T. A. (2013). Efek gender dan pendidikan pada hubungan kecerdasan emosional dan kinerja karyawan BPR di Kabupaten Gianyar. E-Jurnal Ekonomi dan Bisnis Universitas Udayana, 2(3), 190-203.

Ruigrok, A. N. V., Salimi-Khorshidi, G., Lai, M.-C., Baron-Cohen, S., Lombardo, M. V., Tait, R. J., \& Suckling, J. (2014). A meta-analysis of sex differences in human brain structure. Neuroscience \& Biobehavioral Reviews, 39, 34-50.

Rushton, J. P., \& Ankney, C. D. (2009). Whole brain size and general mental ability: A review. The International Journal of Neuroscience, 119(5), 691731.

Rusmawati, K. R., Tripalupi, L. E., \& Artana, M. (2014). Faktor-faktor yang mempengaruhi terhambatnya penyelesaian studi mahasiswa jurusan pendidikan ekonomi tahun 2012/2013. Jurnal Pendidikan Ekonomi Undiksha, 4(1), 1-10.

Silvia, P. J. (2015). Intelligence and creativity are pretty similar after all. Educational Psychology Review, 27(4), 599-606.

Sternberg, R. J., \& Kaufman, S. B. (2011). The Cambridge handbook of intelligence. Cambrige: Cambridge University Press.

Stoet, G., \& Geary, D. C. (2015). Sex differences in academic achievement are not related to political, economic, or social equality. Intelligence, 48 , 137-151. 
Syah, M. (2010). Psikologi pendidikan: Dengan pendekatan baru. Bandung: Remaja Rosdakarya.

Trinovryan, A., Azlina, N., \& Silfi, A. (2016). Pengaruh kecerdasan emosional, kecerdasan spiritual, dan perilaku belajar terhadap pemahaman akuntansi dilihat dari perspektif gender (studi pada Universitas Riau, Universitas Islam Riau, dan Universitas Islam Negeri Sultan Syarif Qasim II). Jurnal Online Mahasiswa (JOM) Bidang Ilmu Ekonomi, 3(1), 2049-2063.

Voyer, D., \& Voyer, S. D. (2014). Gender differences in scholastic achievement:
A meta-analysis. Psychological Bulletin, 140(4), 1174-1204.

Walgito, B. (2010). Pengantar psikologi umum. Yogyakarta: Andi.

Wang, M. T., \& Degol, J. L. (2017). Gender gap in science, technology, engineering, and mathematics (STEM): Current knowledge, implications for practice, policy, and future directions. Educational Psychology Review, 29(1), 119-140.

Zaidi, Z. F. (2010). Gender differences in human brain: A review. The Open Anatomy Journal, 2, 37-55. 